\title{
MISTURAS VITAMÍNICAS NA REGENERAÇÃO DO MARACUJAZEIRO AMARELO (Passiflora edulis f. flavicarpa Deg.)
}

\author{
VITAMINIC MIXTURES ON YELLOW PASSION FRUIT REGENERATION
}

\author{
Alessandra Ferreira Ribas ${ }^{1}$ Francine Denis $^{2}$ Marguerite Quoirin ${ }^{3}$ Ricardo Antonio Ayub ${ }^{4}$
}

RESUMO

Cotilédones obtidos a partir de sementes germinadas in vitro foram usados como explantes com o objetivo de avaliar o efeito de dois complexos vitamínicos e de duas concentrações de 6- benzilaminopurina (BAP) na organogênese direta do maracujá amarelo (Passiflora edulis $f$. flavicarpa Deg.). Empregou-se o meio Murashige \& Skoog (1962) suplementado com as vitaminas $M S$ ou $B_{5}$ (vitaminas de GAMBORG et al., 1968) e 1 ou $2 \mathrm{mg} \cdot \ell^{1}$ de BAP. Foram testados quatro tratamentos, sendo cada um constituído de 60 explantes. $O$ experimento foi inteiramente casualizado, com dez repetições. Os dados, analisados pelo teste de Tukey, demonstraram que os meios de cultura suplementados com o complexo vitamínico $B_{5}$ induziram gemas em mais de $70 \%$ dos explantes, obtendo-se até 8 brotos por explante, com um enraizamento superior a 90\%. A análise de ploidia das plantas regeneradas indicou um número aparentemente normal de cromossomos típicos dessa espécie $(2 n=18)$

Palavras-chave: organogênese, cultura de tecidos, citologia, Passiflora edulis f. flavicarpa Deg.

\section{SUMMARY}

Cotyledons were used as explants in order to test the effect of different vitamin mixtures and BAP concentrations on yellow passion fruit (Passiflora edulis f. flavicarpa Deg.) in vitro direct organogenesis. They basal medium was constituted of MS salts, supplemented with 1 and $2 \mathrm{mg} \cdot \ell^{1}$ of BAP (6benzilaminopurina). Vitamin mixtures $M S$ and $B_{5}$ were tested. Every assay was done with 60 explants. The data were analyzed by Tukey's test. The medium supplemented with $B_{5}$ vitaminic complex induced an increase of the capacity of cotyledons to regenerate in the presence of both BAP concentrations, as well for the number of explants with buds as for the number of buds per explant. The analysis of ploidy level of regenerated plants showed a number of chromosomes apparently normal and typical for this specie $(2 n=18)$.

Key words: organogenesis, tissue culture, cytology, Passiflora edulis $f$. flavicarpa.

\section{INTRODUÇÃO}

O maracujázeiro pertence à família Passifloraceae da ordem Passiflorales, a qual compreende 4 gêneros, incluindo 580 espécies, com distribuição principalmente nos trópicos, das quais mais de 150 são nativas do Brasil (OLIVEIRA, 1987; TEIXEIRA, 1994). Passiflora edulis f. flavicarpa Deg é a espécie cultivada mais importante, conhecida como maracujazeiro amarelo ou azedo, destinada ao abastecimento das indústrias de suco ou à comercialização in natura (SÃO JOSÉ, 1994).

As técnicas de cultura in vitro oferecem uma boa alternativa para o maracujazeiro, pois podem produzir em grande escala clones selecionados de variedades com interesse comercial (FREITAS, 1997).

Em maracujazeiros, apenas a adição de uma citocinina ao meio de cultura, geralmente, promove a resposta esperada de regeneração de gemas, provavelmente porque a quantidade endógena de auxina existente no explante seja suficiente para estabelecer o equilíbrio necessário à

\footnotetext{
${ }^{1}$ Engenheiro Agrônomo, Mestre em Produção Vegetal.

${ }^{2}$ Acadêmico de Agronomia, Universidade Estadual de Ponta Grossa (UEPG).

${ }^{3}$ Engenheiro Agrônomo, Professor, Doutor, Departamento de Botânica, Setor de Ciências Biológicas, Universidade Federal do Paraná.

${ }^{4}$ Engenheiro Agrônomo, Professor, Doutor, Departamento de Fitotecnica e Fitossanidade, UEPG. Praça Santos Andrade s/n, 84010-330, Ponta Grossa, PR. E-mail: rayub@uepg.br Autor para correspondência.
} 
diferenciação (MORAN ROBLES, 1978). A organogênese direta é facilmente induzida em explantes de maracujazeiro (Passiflora edulis f. flavicarpa) em meio MS na presença de 1 a $2 \mathrm{mg} . \ell^{-1}$ de BAP e os brotos regenerados podem ser utilizados em seguida para a micropropagação (KANTHARAJAH \& DODD, 1990; VESTRI $\boldsymbol{e}$ t al., 1990; DORNELAS E VIEIRA, 1994; KAWATA $\boldsymbol{e t}$ al., 1995; FARIA \& SEGURA, 1997ab).

Segundo BARWALE et al. (1986), citado por GEORGE (1993), o conteúdo de tiamina do meio MS pode não ser suficiente para obter ótimos resultados em algumas culturas. Além disso, segundo OHIRA et al. (1976), para cultura de células, as espécies podem ser divididas em dois grupos de acordo com seu requerimento em tiamina. Um grupo inclui soja, fumo e arroz, que requer tiamina, e outro, inclui Ruta e amendoim, que pode crescer em meios de cultura desprovidos desta vitamina. GAMBORG et al. (1968) compararam o complexo vitamínico $\mathrm{B}_{5}$ e o uso de tiamina sozinha no cultivo de células de soja e verificaram que somente a tiamina era necessária para o crescimento das células.

Este trabalho teve por objetivo testar os complexos vitamínicos MS e B5 em combinação com duas doses de BAP na organogênese in vitro de maracujazeiro amarelo (Passiflora edulis f. flavicarpa Deg), como forma de otimizar o método de transferência gênica.

\section{MATERIAL E MÉTODOS}

\section{Material vegetal}

O material vegetal foi obtido a partir de sementes germinadas in vitro, das quais se retiraram cotilédones que foram utilizados como fonte de explantes para os ensaios de regeneração.

\section{Meios de cultura}

Quatro tratamentos resultantes da combinação de duas concentrações de BAP e vitaminas foram testados para regeneração: dois tratamentos testando o complexo vitamínico MS com 1 e $2 \mathrm{mg} . \ell^{-1}$ de BAP (DORNELAS \& VIEIRA, 1994) e outros dois testando o complexo vitamínico $\mathrm{B}_{5}$ com 1 e $2 \mathrm{mg} . \ell^{-1}$ de BAP (SILVA, 1998). No meio de cultura básico, foram utilizados os sais MS (Murashige \& Skoog, 1962) acrescidos de 30g. $\ell^{-1}$ de sacarose. Os meios foram solidificados com 2,6g. $\ell^{-1}$ de Phytagel ${ }^{\circledR}$ (Sigma Chemical Company, USA). $\mathrm{O}$ pH foi ajustado para $5,8 \mathrm{com} \mathrm{NaOH} 0,1 \mathrm{~N}$ antes da adição do Phytagel. Os meios foram esterilizados por autoclavagem durante 20 minutos ( $1 \mathrm{~atm}$ ), distribuindo-se $20 \mathrm{~m} \ell$ de meio por placa de petri esterilizada.

\section{Preparo do explante}

Os cotilédones foram cortados em seis explantes de 0,3 a $0,5 \mathrm{~cm}^{2}$, após a retirada da nervura central. Cada tratamento foi constituído de dez placas com 6 explantes. Os explantes foram colocados com a face adaxial em contato com o meio de cultura. As placas foram seladas com filme plástico de polietileno.

\section{Incubação}

As culturas foram mantidas à temperatura de $25 \pm 2^{\circ} \mathrm{C}$ no escuro durante uma semana, sendo posteriormente transferidas para luz $(9,75 \mu \mathrm{mo} \ell$. $\mathrm{m}^{-2} \cdot \mathrm{s}^{-1}$ ) com fotoperíodo de $16 \mathrm{~h}$. Durante dois meses, os explantes foram subcultivados a cada 15 dias, alternando meios suplementados ou não com BAP.

\section{Análise estatística}

Foram calculadas as porcentagens de explantes com brotos e o número médio de brotos por explante. $\mathrm{O}$ delineamento experimental foi inteiramente casualizado, com dez repetições. A análise de variância foi realizada em esquema bifatorial $(2 \times 2)$. As médias foram comparadas pelo teste de Tukey, a 5\% de probabilidade de erro.

\section{Enraizamento}

Após 2 meses de cultura, os brotos regenerados foram transferidos para os meios MS e MS com vitaminas $B_{5}$, em que as concentrações de sais, vitaminas e sacarose foram diluídas pela metade. Como os brotos desenvolveram-se assincronicamente, foram selecionados 20 dos mais desenvolvidos, em cada meio, os quais foram transferidos para caixas de tipo Magenta ${ }^{\circledR}$ Sigma, (5 brotos em cada caixa), para análise do enraizamento após 30 dias de cultivo.

\section{Aclimatação}

Plantas enraizadas in vitro foram retiradas do meio de cultura e tiveram suas raízes lavadas. Em seguida, foram transplantadas para potes plásticos, contendo substrato esterilizado por autoclavagem (1atm por 20min) na proporção de 1 solo: 1 vermiculita $(\mathrm{v} / \mathrm{v})$.

Os potes permaneceram em uma miniestufa coberta com plástico polietileno, saturada com água para manter a umidade, por 15 dias. $\mathrm{O}$ plástico foi removido gradualmente a partir de 7 dias, e as plantas, transferidas para casa de vegetação. 


\section{Citologia}

Ápices radiculares foram excisados no momento do transplantio para fase de aclimatação, um mês após essa fase, estando as plantas já no substrato. Os mesmos foram pré - tratados com 0,03\% de 8-hidroxiquinolina $\left(\mathrm{C}_{6} \mathrm{H}_{7} \mathrm{NO}\right)$ por 4 horas e fixados em 1:3 ácido acético e álcool etílico absoluto, por 24 horas, transferidos para álcool $70 \%$ e conservados em geladeira.

A coloração foi feita pelo método de Feulgen (MELLO \& VIDAL, 1978). As lâminas foram observadas em microscópio ótico. Foram analisadas 12 plantas regeneradas. Ápices radiculares de plantas originadas de sementes foram usadas como controle.

\section{RESULTADOS E DISCUSSÃO}

\section{Regeneração de brotos}

A indução de brotos ocorreu via organogênese direta (brotação adventícia). A resposta morfogenética pôde ser observada após 10 dias de cultivo. A análise de variância mostrou que não houve interação significativa entre os fatores vitaminas $\mathrm{x}$ concentração de BAP (dados não apresentados). Aos 30 dias, avaliou-se o número de explantes que formaram brotos (Tabela 1). Ocorreram diferenças significativas na porcentagem de explantes com brotos, tanto em função do complexo vitamínico quanto das doses de BAP (Tabela 1).

Tabela 1 - Porcentagem de regeneração e número médio de brotos por explante obtidos a partir de cotilédones de maracujazeiro amarelo (Passiflora edulis f. flavicarpa Deg.) cultivados em meio MS com diferentes misturas de vitaminas.

\begin{tabular}{|c|c|c|c|}
\hline \multicolumn{4}{|c|}{ CONCENTRAÇÃO DE BAP $\left(\mathrm{mg} \cdot \ell^{-1}\right)$} \\
\hline VITAMINAS & 1 & 2 & Média \\
\hline \multicolumn{4}{|c|}{ Porcentagem de explantes com brotos } \\
\hline $\mathrm{B}_{5}$ & $71,7^{*}$ & 78,4 & $75,05 \mathrm{~A}^{* *}$ \\
\hline MS & 43,4 & 51,7 & $47,55 \mathrm{~B}$ \\
\hline Média & $57,55 \mathrm{~b}$ & $65,05 \mathrm{a}$ & \\
\hline $\mathrm{CV}(\%)$ & & & 4,17 \\
\hline \multicolumn{4}{|c|}{ Número médio de explantes com brotos } \\
\hline $\mathrm{B}_{5}$ & 6,51 & 8,38 & $7,45 \mathrm{~A}$ \\
\hline MS & 4,61 & 5,40 & $5,01 \mathrm{~B}$ \\
\hline Média & $5,56 \mathrm{~b}$ & $6,89 \mathrm{~b}$ & \\
\hline $\mathrm{CV}(\%)$ & & & 17,08 \\
\hline
\end{tabular}

** Dados transformados em $\operatorname{arcsen} \sqrt{\mathbf{X}}$

***édias não seguidas pelas mesmas letras minúscula na horizontal e maiúscula na vertical diferem significativamente entre si pelo teste de Tukey a $5 \%$ de probabilidade de erro.
Os meios de cultura suplementados com o complexo vitamínico $\mathrm{B}_{5}$ induziram maior porcentagem de explantes com brotos (acima de $71 \%$ ) em ambas as concentrações de BAP. A porcentagem e o número médio de brotos por explante foram superiores em ambos os meios suplementados com $2 \mathrm{mg} \cdot \ell^{-1}$ de BAP. O número médio de brotos por explante observado no meio contendo as vitaminas $\mathrm{B}_{5}$ e $2 \mathrm{mg} \cdot \ell^{-1}$ de $\operatorname{BAP}(78,4 \%)$ foi superior ao número obtido com os outros tratamentos (Tabela 1). Meios suplementados com complexo vitamínico MS mostraram resultados inferiores $(51,7$ e 43,4\%) ao encontrado por DORNELAS \& VIEIRA (1994), que obtiveram $66,7 \%$ de gemas no meio de cultura contendo sais e vitaminas MS, suplementado com $1 \mathrm{mg} . \ell^{-1}$ de BAP. Talvez este fato se deva a diferenças de idade dos explantes, condições de germinação da semente e genótipo utilizado. Por outro lado, os resultados obtidos nos meios suplementados com o complexo vitamínico $\mathrm{B}_{5}$ foram superiores (71 e 78\%) aos obtidos por DORNELAS \& VIEIRA (1994), tanto para 1 quanto para $2 \mathrm{mg} \cdot \ell^{-1}$ de BAP (respectivamente), e similares aos de SILVA (1998) embora o mesmo tenha utilizado explantes foliares. $\mathrm{O}$ uso de complexo vitamínico $\mathrm{B}_{5}$ também foi responsável pelo aumento no número de brotos por explante. Este resultado pode ser justificado devido à concentração de tiamina das vitaminas $\mathrm{B}_{5}$ ser 100 vezes maior e a do ácido nicotínico e da piridoxina 2 vezes maiores do que as do meio MS.

Há um estreito relacionamento entre o grau de desdiferenciação das células cultivadas e o seu requerimento em tiamina: quanto mais alto o grau, maior o requerimento (OHIRA et al., 1976). Os resultados sugerem que, para o maracujazeiro, o aumento na concentração de vitaminas no meio de cultura, intensifica a formação de gemas.

GEORGE (1993) sugere que há uma interação sinergística entre tiamina e reguladores de crescimento da classe das citocininas. DIGBY \& SKOOG (1966) verificaram que altas concentrações de cinetina ativam a biosíntese dessa vitamina pelos tecidos de plantas de fumo; o mesmo acontece com $2 \mathrm{iP}$ e BAP, as quais foram ativas da mesma maneira que a cinetina.

\section{Crescimento e Enraizamento}

Após 2 meses de subcultivo (a cada 15 dias), os brotos permaneceram por mais 30 dias em meios sem reguladores de crescimento para permitir os seus crescimentos. As citocininas possuem efeito residual, fazendo-se necessária uma fase intermediária de crescimento com o objetivo de eliminar o efeito desse grupo de substâncias nas 
culturas antes do enraizamento (RUGINI \& VERMA, 1982). Após 15 dias de cultivo nos meios diluídos $\mathrm{MS} / 2$ e $\mathrm{MSB}_{5} / 2$, iniciou-se a formação de raízes. O enraizamento dos brotos ocorreu em torno de $80-93 \%$, nestes meios (respectivamente). O cultivo em sistema de alternância entre meios suplementados e não suplementados com reguladores de crescimento parece ter sido decisivo para o enraizamento in vitro. A adição de auxina não foi necessária para promover o enraizamento das plantas regeneradas, como anteriormente observado para espécies de Passiflora (MORAN ROBLES, 1978; DORNELAS E VIEIRA, 1994; FREITAS, 1997; FARIA \& SEGURA, 1997a). No trabalho de KAWATA et al. (1995), a presença de auxinas no meio de regeneração, como ácido indolbutílico (AIB), ácido naftaleno acético (ANA) e ácido 2,4diclorofenoxiacético (2,4D) não promoveu enraizamento nem desenvolvimento de brotos. Ao contrário, as auxinas produziram calos na base dos brotos transplantados, o que está de acordo com as observações de AYUB (2000 - Informe verbal).

\section{Transplante e aclimatação}

Plantas mostraram taxa de sobrevivência em torno de $100 \%$, independente do meio de cultura in vitro. Neste trabalho, não houve necessidade de poda das raízes e nem eliminação de todas as folhas para garantir altas taxas de sobrevivência na aclimatação de plantas de maracujazeiro regeneradas in vitro, como sugerido por FARIA \& SEGURA (1997b). Plantas de maracujá sem raízes visíveis, transferidas para fase de aclimatação in vivo tiveram um bom desenvolvimento, sugerindo que não é essencial a formação de raízes para garantir a sobrevivência e o desenvolvimento das mesmas (FREITAS, 1997), o que está de acordo com nossas observações. Em todos os casos, a manutenção da alta umidade foi essencial.

\section{Citologia}

A maioria das células analisadas encontrava-se em prófase. Quando o tempo de ação da hidroxiquinolina foi aumentado para 5 horas, células em metáfase foram visualizadas e o número de cromossomos determinado.

As plantas obtidas in vitro exibiram o número diploide aparentemente normal de cromossomos típicos da espécie Passiflora edulis f. flavicarpa Deg $(2 \mathrm{n}=18)$, em todas as plantas analisadas (dados não mostrados). Plantas produzidas por brotos pré - formados têm alta chance de ser fenotipicamente normais (GEORGE, 1993).

\section{CONCLUSÕES}

A combinação da vitamina $\mathrm{B}_{5}$ com $2 \mathrm{mg} . \ell^{-1}$ de BAP resultou num maior número de brotos por explante, que se desenvolveram normalmente, apresentando o número de cromossomos típicos da espécie. A aclimatação é muito fácil, não necessitando que os brotos já estejam enraizados.

A otimização das técnicas de regeneração in vitro permitirá a obtenção de clones selecionados de maracujá amarelo em grande escala, e possibilitará ensaios de melhoramento desta cultura, por técnicas de transformação genética.

\section{AGRADECIMENTOS}

À pesquisadora Neusa Maria Colauto Stenzel do Instituto Agronômico do Paraná, pelo fornecimento das sementes de Maracujá Amarelo. Ao fotógrafo Jeferson (UEPG), Ao CNPq pelo suporte financeiro.

\section{REFERÊNCIAS BIBLIOGRÁFICAS}

DIGBY, J., SKOOG, F. Cytokinin activation of thiamine biosynthesis in tobacco callus cultures. Plant Physiology, Lancaster, v.41, p.647-652, 1966.

DORNELAS, M.C., VIEIRA, M.L.C. Tissue culture studies on species of Passiflora. Plant Cell, Tissue and Organ Culture, Dordrecht, v.36, p.211-217, 1994.

FARIA, J.L.C., SEGURA, J. In vitro control of adventitious bud differentiation by inorganic medium components and silver thiosulfate in explants of Passiflora edulis f. flavicarpa. In Vitro Cellular Developmental Biology-Plant, Calgary, v.33, n.3, p.209-212, 1997a.

FARIA, J.L.C., SEGURA, J. Micropropagation of yellow passionfruit by axillary bud proliferation. HortScience, Michigan, v.32, n.7, p.1276-1277, 1997b.

FREITAS, I.M.N. Micropropagação in vitro de maracujazeiro. Actas de Horticultura. Vilamoura, v.18, p.103-106, 1997

GAMBORG, O.L., MILLER, R., OJIMA, K. Nutrient requirement of suspension cultures os soybean root cells. Experimental Cell Research, New York, v.50, p.151-158, 1968

GEORGE, E.F. Plant propagation by tissue culture. Part 1 The tecnology. England: Wilts, 1993. 574p.

KANTHARAJAH, A.S., DODD, W.A. In vitro micropropagation of Passiflora edulis (purple passionfruit). Annals of Botany, London, v.65, p.337-339, 1990.

KAWATA, K., USHIDA, C., KAWAI, F., $\boldsymbol{e}$ t $\boldsymbol{a l}$. Micropropagation of passion fruit from subcultured multiple shoot primordia. Journal of Plant Physiology, Stuttgart, v.147, p.281-284, 1995.

MELLO, M.L.S., VIDAL, B.C. A reação de Feulgen. Ciência e Cultura, Campinas, v.30, n.6, p.665-676, 1978. 
MORAN ROBLES, M.J. Multiplication végétative, in vitro, des bourgeons axillaires de Passiflora edulis var. flavicarpa Degener et de P. molissima Bailey. Fruits, Paris, v.33, n.10, p.693-699, 1978.

MURASHIGE, T., SKOOG, F. Revised medium for rapid growth and bioassays with tobacco tissue cultures. Physiologia Plantarum, Copenhagen, v.15, p.473-497, 1962.

OHIRA, K. IKEDA, M. OJIMA, K. Thiamine requirements of various plant cells in suspension culture. Plant \& Cell Physiology, Rockiville, v.17, p.583-590, 1976.

OLIVEIRA, J.C. Melhoramento genético do maracujazeiro. In RUGGIERO, C (ED). A cultura do maracujá. Ribeirão Preto : Legis Summa, 1987. Cap.23, p.218-246.

RUGINI, E., VERMA, D.C. Micropropagation of difficult to propagate almond (Prunus amygdalus, Batsch) cultivar. Plant Science Letters, Amsterdam, v.28, p.273-281, 1982.
SÃO JOSÉ, A.R. Maracujá, produção e mercado. Vitória da Conquista : DFZ / UESB, 1994. 255p.

SILVA, M.B. Transformação genética de maracujáamarelo (Passiflora edulis f. flavicarpa Deneger) mediada por Agrobacterium tumefaciens. Viçosa, 1998. 45p. Dissertação (Mestrado em Botânica) - Curso de Genética e Melhoramento, Universidade Federal de Viçosa, 1998.

TEIXEIRA, C.G. Cultura. In: ITAL - Campinas (Ed.) Maracujá: cultura, matéria-prima, processamento e aspectos econômicos. Campinas : Ital, 1994. Cap.1, p.1142.

VESTRI, F., SCHIFF, S., BENNICI, A. In vitro shoot regeneration in Passiflora coerulea. Acta Horticulturae, Wageningen, n.280, p.105-107, 1990.

Ciência Rural, v. 32, n. 2, 2002. 